\title{
RECYCLING OF FOUNDRY SAND WASTES IN SELF-COMPACTING MORTARS: USE AS CEMENTITIOUS MATERIALS AND FINE AGGREGATES
}

\author{
SEBKI Ghania ${ }^{\text {a }}$, SAFI Brahim ${ }^{\text {a }}$ *, CHAHOUR Kahina ${ }^{\text {a, b }}$ \\ ${ }^{a}$ University M'Hamed Bougara- Boumerdes Frantz fanon city, Research Unit: Materials, Processes and Environment, (UR/MPE), \\ Boumerdes, 35000, Algeria, e-mail: *safi_b73@univ-boumerdes.dz \\ ${ }^{\mathrm{b}}$ University Mouloud Mammeri of Tizi Ouzou Hasnoua road, Faculty of Construction Engineering, Civil Engineering Department, \\ Tizi Ouzou, 15000, Algeria
}

Received: 21.06.2019 / Accepted: 06.09.2019/ Revised: 10.10.2019 / Available online: 10.12.2019

DOI: $10.2478 /$ jaes-2019-0027

KEY WORDS: foundry sand wastes, self-compacting mortars, slump test, compressive strength, tensile strength, stress-strain.

\begin{abstract}
:
This work aims to study the possibility recycling of foundry sand wastes (FSW) as a cementations additive and fine aggregate in selfcompacting mortars (SCM). For this, an experimental study was carried out to evaluate physical and mechanical properties of SCM. Firstly, sand is substituted by the foundry sand waste at dosages $(0 \%, 10 \%, 30 \%$, and $50 \%)$ by weight of the sand. Secondly cement is partially substituted by crushed foundry sand waste at different ratio $(0 \%, 10 \%, 20 \%, 30 \%$, and $50 \%)$ by weight of cement. The obtained results show that up to 50\%, (FSW) can be used as fine aggregate for mortars without affecting the essential proprieties of mortar. However, beyond 50\% of sand substitution, mortars lose their fluidity. The compressive strength of the mortars with 50\% of cement substitution decreased compared to the control mortar. Value of the highest compressive strength recorded at 28 days, is of the order of $50 \mathrm{MPa}$ for the mortar with $20 \%$ of cement substitution. Also, stress-strain curve show an acceptable mechanical behavior of FSW-based mortar at $50 \%$ of sand substitution.
\end{abstract}

\section{INTRODUCTION}

Currently, foundry wastes occupy their place in the field of construction materials as supplementary materials (Farooq et al., 2014; Amitkumar et al. 2015; Khatib et al., 2010; Salokhe and Desai, 2014). Among these wastes, it can be cited foundry sand which contains high quality silica with interesting physical characteristics. Many works have studied on the foundry sand in recent years which can be cited in the following: use of foundry in hydraulic barriers (Abichou et al., 1998, 2000); in asphalt concrete (Bakis et al., 2006); usage opportunity as waste material in civil engineering and recycling (TRB, 1994; Reddi et al., 1995); recycling and removal off waste foundry (Senske, 1970 ) etc. Foundry sands are by-products of the metal casting industries (ferrous and non-ferrous) whose sand can be re-used and recycled as a molding material because of its thermal properties. Foundry sands have physical and chemical characteristics that will depend largely on the type of casting process and the industrial sector from which it is derived (Salokhe and Desai, 2014; Sen and Mishra, 2010; De Koff et al., 2008; Mgangira, 2006). Several studies have been carried on the use of WFS in cement mortars of concrete materials, either as filling material or as fine aggregates. Naik et al. (Naik et al., 1996) have found that with use of foundry sand in concrete, the workability reduced and Compressive strength of concrete slightly decreased due to the replacement of regular coarse aggregate with foundry sand. However, other studies (Naik et al., 1996; Singh and Siddique, 2012; Farooq et al., 2014; Amitkumar et al. 2015) investigated some fresh and hardened properties of concrete containing waste foundry sand (WFS). They noticed that there is a loss in workability of studied concretes as function as foundry sand content. By cons, an increasing in compressive strength of all concrete mixes (with and without WFS) was observed with curing age. However, compressive strength of concrete has also decreased with increasing amounts of WFS. This decrease has been explained that WFS absorbed more water. Regarding the use of WFS as sand in the cement mortars, Monosi et al, (Monosi et al., 2010) investigated the properties of mortars containing different dosages of used foundry sand (WFS) as partial replacement of sand. According to their results, they concluded that, at same w/c ratio the WFS has reduced the fluidity when added as natural sand replacement and higher amount of superplasticizer is required in order to maintain the same fluidity. Similarly, they have found that a decreasing of compressive strength was observed by using of WFS as sand in 
concrete (Lawrence and m. Mavroulidou, 2009; Fiore and Zanetti, 2007; Khatib et al., 2010, 2011; Da Silva et al., 2011). According to this modest bibliographic research on the use of foundry sand wastes, it is still interesting to see also its influence on the properties of a fluid mortar, namely selfcompacting mortars. For this, the main objective of this work is to replace sand or cement by a waste, technique objective: to have a self-compacting mortar of comparable quality to control mortar and finally environmental objective: recycling of a foundry sand waste. So we have to study the effect of substitution sand and cement by foundry sand waste on the physico-mechanical properties of self-compacting mortars. Sand is substituted by foundry sand waste $(0-5 \mathrm{~mm})$ at ratio $(0,10$, 30,50 , and $100 \%$ ) by weight of sand noted respectively (MS0, MS10, MS30, MS50, MS100). And also the cement substituted by foundry sand waste at dosage $(0,10,20,30$, and $50 \%)$ by weight of cement noted (MC0, MC10, MC20, MC30, MC50).

\section{EXPERIMENTAL STUDY}

\subsection{Materials used}

The materials used in this study are: Portland cement (CEM II 42, 5), limestone filler, Polycarboxylate based superplasticizer (from SIKA, Tempo 12 type), natural sand NS (0/5mm), foundry sand waste (FSW).

The foundry sand waste used (figure1) in our work is a recycling waste from Algeria foundry. This waste was characterized; it has a special feature of form. Indeed, the shape of this waste is an angular one. It is remarkable that (FSW) contain essentially silica (table 1). Therefore, the characteristics of this sand are determined either at natural state and crushed state. The physical properties of Natural Sand (NS) and WFS are given in Table 2. From table 2, it was noted that WFS-sand is finer than natural sand according the obtained fineness modulus of the used sands.
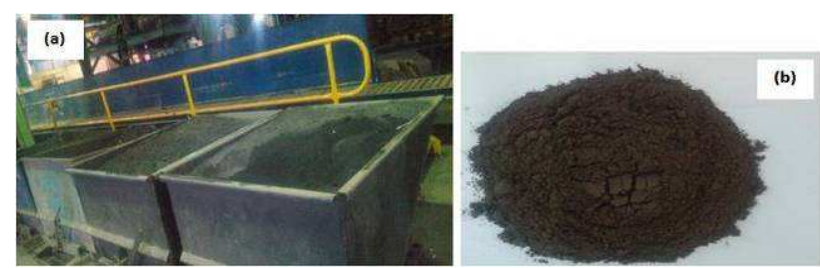

Figure 1. Foundry sand wastes used in this work (a) rejected zone (b) FWS as sand

Table 1 . Chemical analysis of foundry sand waste by X-ray fluorescence

\begin{tabular}{llllllllll}
\hline Compounds & $\mathrm{CaO}$ & $\mathrm{SiO}_{2}$ & $\mathrm{Al}_{2} \mathrm{O}_{3}$ & $\mathrm{Fe}_{2} \mathrm{O}_{3}$ & $\mathrm{SO}_{3}$ & $\mathrm{Na}_{2} \mathrm{O}$ & $\mathrm{K}_{2} \mathrm{O}$ & $\mathrm{MgO}$ & $\mathrm{P}_{2} \mathrm{O}_{5}$ \\
\hline & 6.328 & 60.762 & 11.688 & 9.642 & 1.851 & 0.010 & 1.281 & 2.195 & 0.010 \\
\hline
\end{tabular}
\begin{tabular}{llllllllllll} 
(\%) & & 6.328 & 60.762 & 11.688 & 9.642 & 1.851 & 0.010 & 1.281 & 2.195 & 0.010 \\
\hline
\end{tabular}

Table 2. Physical properties of Natural Sand and Foundry Sand Wastes

\begin{tabular}{|lcc|}
\hline & Natural Sand & Foundry Sand Wastes \\
& NS & WFS \\
\hline Apparent density & 1550 & 1240 \\
$\left(\mathrm{~kg} / \mathrm{m}^{3}\right)$ & 2510 & 2400 \\
Specific gravity & 3.67 & 2.47 \\
$\left(\mathrm{~kg} / \mathrm{m}^{3}\right)$ & & \\
Fineness modulus & & \\
\hline
\end{tabular}


mixes details of control mortar (SCM0) and others variants were obtained by using FSW as sand substitution at dosages $(10,30$, and $50 \%$ wt. of sand), and by cement substitution at ratio $(10,20,30$ and $50 \%$ wt. of cement $)$. The ratio $(\mathrm{F} / \mathrm{C}=0.10)$ is kept constant. The mixing protocol was kept constant for all mortar mixtures.

Table 3. Details of self-compacting mortar mixtures

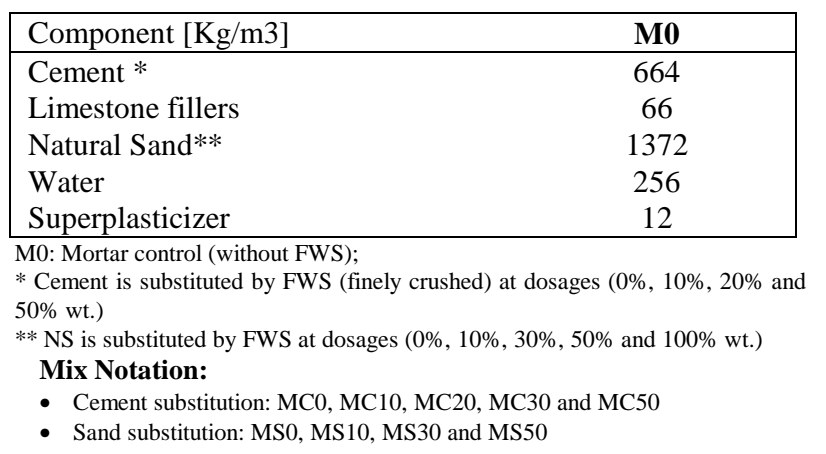

\subsection{Preparation, curing and test methods}

Fresh properties: After each preparation, the fluidity of the freshly prepared mortar was evaluated to ensure the mini-slump flow diameter suitable for self-compacting concrete according to RFNARC (RFNARC Norm, 2002).

Hardened Properties: For hardened properties of mortars,

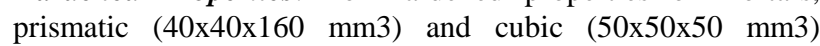
samples were manufactured for each mixture. One day after casting, samples were stored in water under $21 \pm 1^{\circ} \mathrm{C}$. The various tests and measurements were carried out in order to study mechanical (bending strength, uniaxial compression and mechanical behaviour) properties.
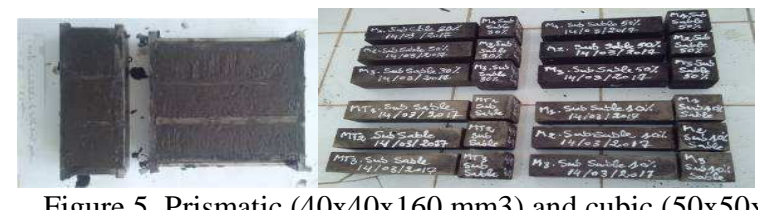

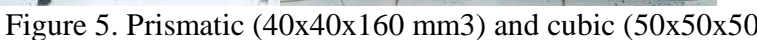
$\mathrm{mm} 3$ ) samples of mortars

Three-point bending and uniaxial compression tests are carried out at 2, 7 and 28 days on water stored samples. Three-point bending tests were carried out on prismatic samples according to ASTM C348 (ASTM C348 norm, 2008). Cubic samples were subjected to compressive stress by using a hydraulic press with a capacity of $3000 \mathrm{KN}$ according to ASTM C349 (ASTM C349 norm, 2008). From the stress-strain curve, mechanical behavior for mortars was obtained experimentally using a compression uniaxial.

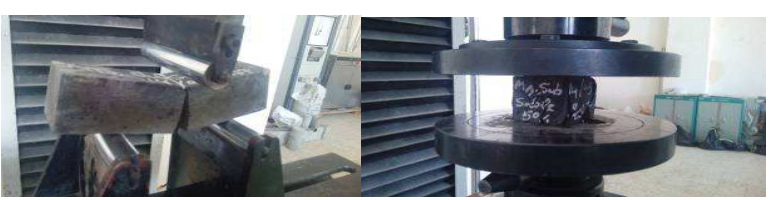

Figure 6. Mechanical tests (compressive and flexural strength)

\section{RESULTS AND DISCUSSIONS}

\subsection{Cement Substitution}

\subsubsection{Fluidity of mortars}

The mortar fluidity is tested by mini-cone and the results are given in Figure 7. According this figure, all studied mortars show fluidity suitable for self-compacting mortars is varying between 180 and $220 \mathrm{~mm}$. However compared to MC0, a decreasing of the fluidity mortars is observed. Beyond $50 \%$ of substitution, self-placing mortars lose their fluidity. It should be noted that this fluidity can be made up by increasing the dosage of the superplasticizer.

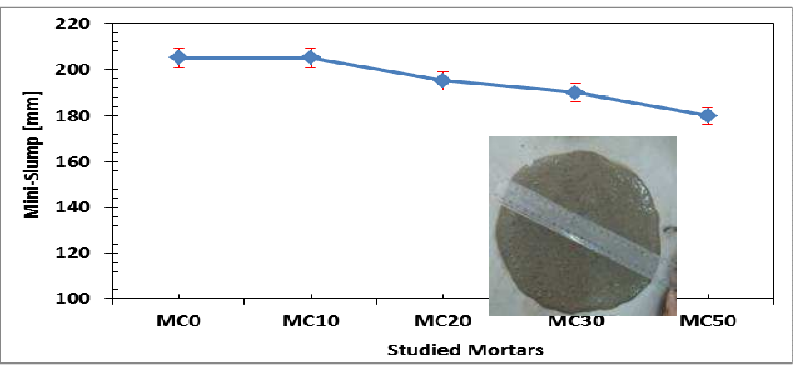

Figure 7. Fluidity of mortars studied by cement substitution

\subsubsection{Compressive and flexural strength}

Flexural tensile and uniaxial compression tests were performed at 2, 7, and 28 days of cure. Evolution of the flexural and the compressive strength for all the studied mortars at different curing age is given in Figure 8. According to obtained results, it is evident that the mechanical strength increases as a function of curing age for all mortars. This is can be explained by cement hydration products. However, it is noted that the flexural strength is constant for cement substitution by FSW MC10 and MC20 compared MC0, a reduction of the strength for $30 \%$ and $50 \%$ of substitution (figure $6(a)$ ).
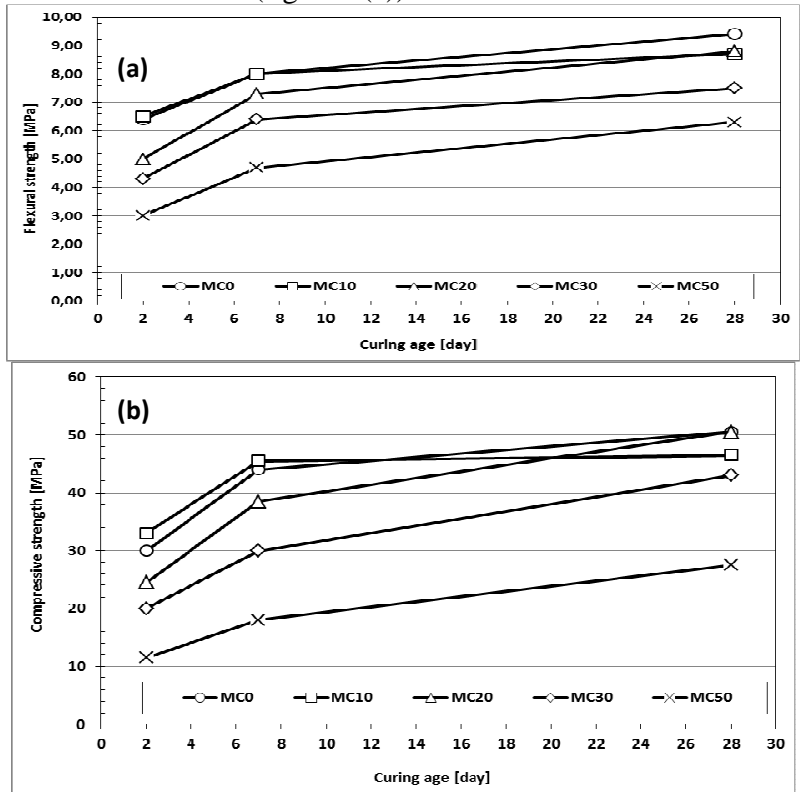

Figure 8. Mechanical strength development of studied selfcompacting mortars (a) flexural (b) compressive; Cement substitution case

It is found that the compressive strength for the mortar is practically the same for mortars MC0, MC10, MC20, for cement substitution for SFW. However, beyond the 30\% foundry sand waste a decrease of compressive strength is not significant (Figure 8). The resistance for 50\% substitution the decreases, the value of the highest compressive strength at 28 
days recorded is of the order of 50.5 MPa for the mortar of $20 \%$ cement replacement

\subsection{Sand substitution}

\subsubsection{Fluidity of mortars:}

According to the fresh test results, fluidity of mortars decreased with the increase in the substitution rate of sand by waste foundry sand (Figure 9). Indeed, up to $50 \%$ of substitution the decrease is not important; the mortar meets the requirements of concretes self- compacting mortar. Beyond $50 \%$ substitution, self-compacting mortars lose their fluidity.

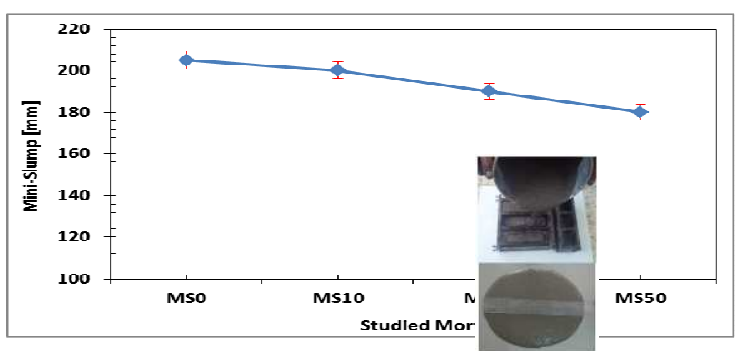

Figure 9. Fluidity of mortars studied by sand substitution

\subsubsection{Compressive and flexural strength}

From the obtained results, the flexural strength is constant for the case of the sand substitution $10 \%$ and $30 \%$ compared with the control mortar, decrease in resistance for $50 \%$ substitution is not important. There is also significant reduction in the resistance for a $100 \%$ substitution compared with the control mortar (figure 10(a)). The results of the compression resistance of the mortars are given in Figure 10(b), the strength increases as a function of the cure time, it is noted that the resistance value of the mortars is practically the same for mortars MS0 and MS10 substitution of sand. However, above $30 \%$ and 50\% sand substitution, the resistance decreases, the value of the highest compressive strength is of the order of $49 \mathrm{MPa}$ for the mortar of $10 \%$ of substitution of sand. The resistance value for $100 \%$ total substitution of the sand is very low compared to the control mortar.
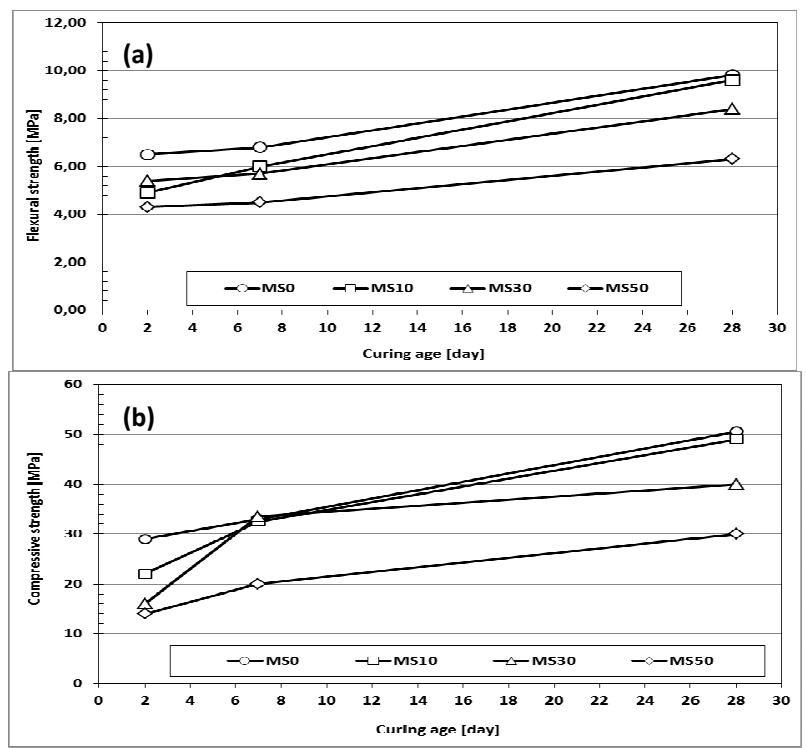

Figure 10. Mechanical strength development of studied selfcompacting mortars (a) flexural (b) compressive; Sand substitution case

\subsection{Mechanical behavior of the studied mortar}

This part of the work is dedicated to the study of the mechanical behavior of mortars studied by uni-axial compression tests carried out on 50x50x50 m3 specimens. For this, it has chosen the compositions of the mortars which gave better results compared to the reference mortar M0, namely the mortar MC10, MC30, MS10 and MS50 respectively, cases of substitution of cement and sand. The results obtained are given in the form of constraint-deformation curve of all the mixtures after 28 days of hardening. Then mechanical behavior for each mortar mixtures was determined experimentally by drawing the stress-strain curve. The results obtained were given in figure 11 .

It is clear that these mortars have a fragile behavior identified by an elastic domain then rupture at a maximum load. However, the MC10 mortar has the same mechanical behavior as the reference mortar MC0. While, up to $30 \%$ cement substitution by foundry sand, mechanical behavior of the mortar is still fragile but a reduction in the maximum charge with a lower deformation compared to the control mortar is observed.
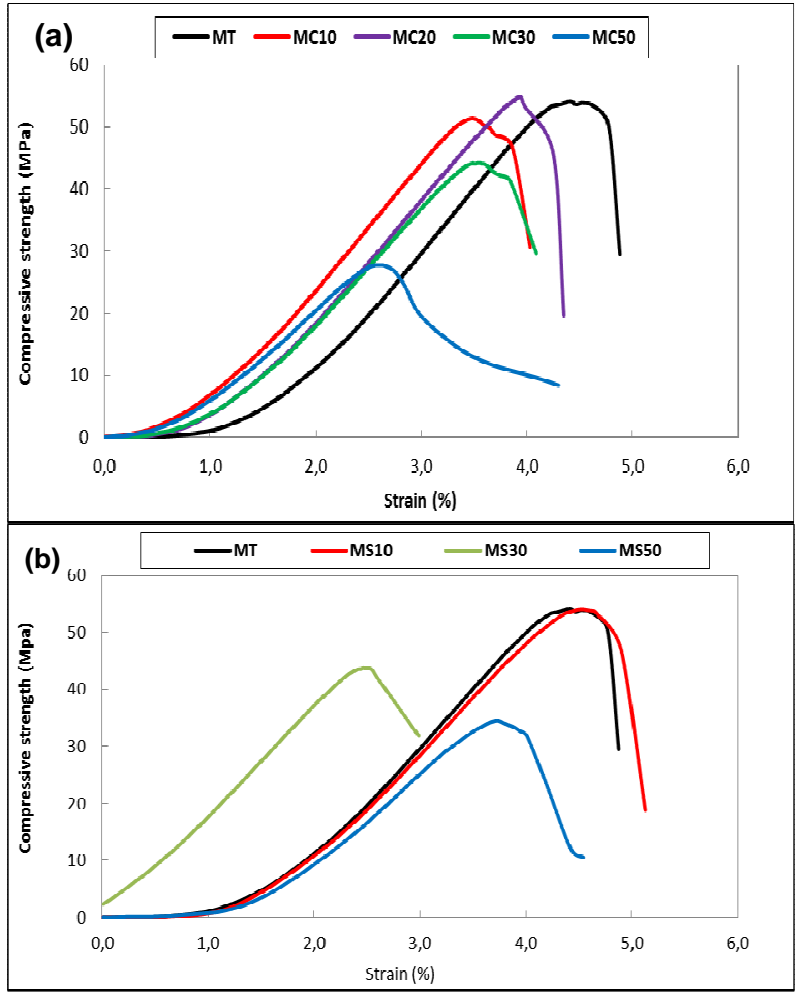

Figure 11. Stress-strain of studied mortars at 28-day (a) cement substitution (b) sand substitution

\section{CONCLUSIONS}

The objective of this study was to recycle foundry sand waste as a cementations additive and fine aggregate (sand) in the formulation of self-compacting mortars. An experimental study was carried out to evaluate the fresh and hardened properties of self-compacting mortars. With partial or total cement substitution by finely ground foundry sand waste and substitution of natural sand by foundry sand waste. Through the experimental study carried out, it can be concluded that: 
- Up to $30 \%$ cement substitution by ground foundry sand, reduction of fluidity of the mortars is not important, or the mortar meets the requirements of self-placing. Beyond $50 \%$ substitution, self-compacting mortars lose their fluidity. It should be noted that this fluidity can be made up by increasing the dosage of the superplasticizer.

- The compressive strength of the mortars for $50 \%$ cement substitution decreased compared to the control mortar. Value of the highest compressive strength recorded at 28 days, is of in order of $50 \mathrm{MPa}$ for the mortar of $20 \%$ cement substitution.

- Concerning the use of foundry sand as sand, up to $50 \%$ substitution the decrease of fluidity mortars is not considerable. At $100 \%$ substitution of natural sand, self-compacting mortars lose their fluidity.

- For mortars with $30 \%$ and $50 \%$ sand substitution, resistance has decreased; value of the highest compressive strength recorded is of the order of $49 \mathrm{MPa}$ for mortar with $10 \%$ sand substitution by waste foundry sand.

- The MS10 mortar with $10 \%$ of foundry sand has a mechanical behavior identical to the reference. While up to $30 \%$ sand substitution by foundry sand, the mechanical behavior of the mortar is still fragile but a reduction in the maximum load with a lower breaking deformation compared to the control mortar is observed.

In this work it has been shown that the cement can be substituted by the foundry sand waste up to $30 \%$ by weight of cement or the mortar meets the requirements of self-compacting mortars from the point of view of fluidity and implementation as well as the mechanical properties. Regarding the use of foundry sand as sand, sand substitution can reach up to $50 \%$ substitution without greatly affecting the physical and mechanical properties of self-compacting mortar.

\section{References:}

Abichou, T., Benson, C.H., Edil, T.B., 2000, Lab study: use of green foundry sand as hydraulic barrier. ASCE Journal of Geotechnical and Geoenvironmental Engineering 126 (12), 1174-1183.

Abichou, T., Benson, C.H., Edil, T.B., Freber, B.W., 1998, Use of waste foundry sand in hydraulic barrier. ASCE American Society of Civil Engineers, Geotechnical Special Publication 79, 86-99.

Amitkumar D., A. Pamnani, Alefiya I. Kachwala, 2015, Foundry Sand: Utilization as a partial replacement of fine aggregate for establishing sustainable concrete, International Journal of Engineering Sciences \& Research Technology, 4(1), January, pp. 308-311.

ASTM C348 - 08, Standard Test Method for Flexural Strength of Hydraulic-Cement Mortars, which appears in the Annual Book of ASTM Standards Vol 04.01.

ASTM C348 - 08, Standard Test Method for Flexural Strength of Hydraulic-Cement Mortars, which appears in the Annual Book of ASTM Standards Vol 04.01.

ASTM C349 - 08, Standard Test Method for Compressive Strength of Hydraulic-Cement Mortars (Using Portions of
Prisms Broken in Flexure), which appears in the Annual Book of ASTM Standards Vol 04.01.

ASTM C349 - 08, Standard Test Method for Compressive Strength of Hydraulic-Cement Mortars (Using Portions of Prisms Broken in Flexure), which appears in the Annual Book of ASTM Standards Vol 04.01.

Bakis, R., Koyuncu, H., Demirbas, A., 2006, An investigation of waste foundry sand in asphalt concrete mixtures, Waste Management Research 24, 269-274.

Da Silva Da Silv, E. Tochetto, L. R. Prudencio and A.L. Oliveira, Influence of foundry sand residues on the fresh and hardened properties of mortars produced with portland cement, IBRACON Structures and Materials Journal, vol.4, No.4, October 2011, 642-662.

De Koff J. P. , B. D. Lee and R. S. Dungan, Amelioration of physical strength in waste foundry Green sands for reuse as a soil amendment, Journal of Environmental Quality, 37, November-December 2008, pp. 2332-2338.

EFNARC Specification and guidelines for self-compacting concrete, Feb. (2002), pp 29-35, Free pdf copy downloadable from http://www.efnarc.org.

Farooq M.U., Ahmed T., Akmal D., and Khurram ND., 2014, Utilization of non-ferrous recycled foundry sand as a partial replacement of fine aggregate in concrete", Sci.Int.(Lahore), 26(40) pp.1527-1431.

Fiore S., M.C. Zanetti, Foundry wastes reuse and recycling in concrete production, American Journal of environmental Sciences, 3 (3), 2007, 135-142.

Khatib J. M., S. Baig, A. Bougara, and C. Booth, Foundry sand utilization in concrete production, Second International Conference on Sustainable Construction Materials and Technologies, June 28-June 30, 2010.

Khatib J.M, B. Baig, B. Menadi and S. Kenai, Waste foundry sand usage in concrete, INVACO2: International Seminar, Innovation \& Valorization In Civil Engineering \& Construction Materials, $\mathrm{N}^{\circ}: 1 \mathrm{P}-137$, University of Wolverhampton, England, United Kingdom, November 23-25,2011, 1-5.

Lawrence D. and m. Mavroulidou, Properties of concrete containing foundry sand, Proceedings of the 11th International Conference on Environmental Science and Technology, Chania, Crete, Greece, 3-5 September 2009, A704- A712.

Mgangira M B , Laboratory assessment of the influence of the proportion of waste foundry sand on the geotechnical engineering properties of clayey soils, Journal Of The South African Institution Of Civil Engineering, Vol 48 No1, March 2006, 2-7.

Monosi S., D. Sani and F. Tittarelli., Used foundry sand in cement mortars and concrete production, The Open Waste Management Journal, 2010, 3, 18-25.

Naik, T.R., Patel V.M., Parikh D.M., Tharaniyil M.P., Application of foundry by-product materials in manufacture of concrete and masonry products. ACI Materials Journal, January-February 1996.

Reddi N.L., Rieck, P.G., Schwab, A.P., Chou, S.T., Fan, L.T., 1995. Stabilization of phenolics in foundry sand using 
cementitious materials. Journal of Hazardous Materials 45, 89106.

Safi B, Saidi M, Daoui A, Bellal A, Mechekak A, Toumi K; The use of seashells as a fine aggregate (by sand substitution) in self-compacting mortar (SCM)" Science Direct, Construction and Building Materials 78 (2015) 430-438.

Safi, B, Saidi, M , Aboutaleb, D, Maallem, M.. The use of plastic waste as fine aggregate in the self- compacting mortars: Effect on physical and mechanical properties. Construction and Building Materials, 43, 436-442. (2013).

Sahmaran M., M. Lachemi, T. K. Erdem and H. Erhan Yucel, Use of spent foundry sand and fly ash for the development of green self-consolidating concrete, Journal of Materials and Structures (2011) 44, 1193-1204.

Salokhe E. P. , D.B. Desai, 2014, Application of foundry waste sand in manufacture of concrete, IOSR Journal of Mechanical and Civil Engineering (IOSR-JMCE), pp. 43-48.

Schwartzentruber A., C. Catherine, Method of the concrete equivalent mortar (CEM) - A new tool to design concrete containing admixture, Materials and Structures. 2000; 33(8): 475-482.

Sen T. and U. Mishra, Usage of industrial waste products in village road construction, International Journal of Environmental Science and Development, 1(2), June 2010, pp. 122-126..

Senske, M.L., 1970. Waste Molding Sand Management Practices, Office of Solid Waste, Environmental Protection Agency Old Reports TO-5/0, p. 15.

Singh G. and R. Siddique, Effect of waste foundry sand (WFS) as partial replacement of sand on the strength, ultrasonic pulse velocity and permeability of concrete, Journal of Construction and Building Materials 26 (2012), 416-422.

TRB, 1994. Aggregates: Waste and Recycled Materials; Soils, Geology and Foundations; Materials and Construction, National Academy of Science Transportation Research Board, TRB/TRR-1437, p. 73. 